\title{
Analysis of variance for parental demographic variables to students' total attitudes toward Secondary education science teaching and learning
}

\author{
Ephias Gudyanga \\ Department of Educational Foundations, Management and Curriculum Studies, Faculty of Education, Midlands State University, Gweru, \\ Zimbabwe
}

\section{Email address:}

gudyangae@gmail.com

\section{To cite this article:}

Ephias Gudyanga. Analysis of Variance for Parental Demographic Variables to Students' Total Attitudes toward Secondary Education Science Teaching and Learning. International Journal of Secondary Education. Vol. 2, No. 2, 2014, pp. 40-47. doi: $10.11648 /$ j.ijsedu.20140202.13

\begin{abstract}
In this study, analysis of variance for parental demographic nt variables to students' total attitudes toward science teaching and learning was carried out. A survey was carried out on a randomly selected 243 participants in the secondary school section (12-16 year age group). The Likert type questionnaire was used to collect data which was subjected to ANOVA testing. The Null hypothesis (Ho) testing showed F-ratios which were significant at both .05 and .01 alpha levels leading to rejection of $\left(\mathrm{H}_{\mathrm{o}}\right)$. Parental encouragement, parental socio-economic status and parental educational levels were all significant towards attitude formations and change towards the teaching and learning of Science. It was concluded that parents play a critical role in encouraging and supporting their children's Science learning at home and in school and throughout their communities.
\end{abstract}

Keywords: Attitude, Parent, Science, Teaching, Learning

\section{Introduction}

Attitudes towards the teaching and learning of Science by students have been found to be a vital issue [1-2] amongst secondary school pupils. In this paper, the study is premised on an attempt to find out the effect of parental antecedent variables against student total attitudes towards the teaching and learning of Science. In their article in press, [3] alluded to the fact that the parental lack of supporting the girl child has an effect on the choice of Advanced Level science subject. This paper shall start by giving the context of the problem, followed by the methodology then findings and their discussion culminating in the laying down of the conclusion(s).

\section{The Context}

A family has a strong influence on the student and his / her educational life. [4] examined 13 studies in which home environment variables were related to student attitudes towards science. Amongst several report findings, [5] found that home environment and parental education exerted a strong influence within a casual chain linking instruction with attitude.

It may be argued that attitude toward any school subject is in itself an important issue in Education. [6] contends that development of positive attitudes towards school subjects is fundamental for 3 reasons: First, attitude seems to be related to achievement and may actually enhance cognitive development. Second, students with a positive attitude toward a subject are more likely to want to extend their learning in that field, both formally an informally, after the direct influence of the teacher has ended. Third, attitude is often communicated to peers in a variety of ways throughout life. A negative attitude may result in lack of support for science and decreased resources for scientific study of society's problems.

It is therefore desirable and imperative to study the determinants of attitude towards science as a school subject and with a view to promoting the development of positive attitudes towards science.

From personal experience as a science teacher for more than thirty years, it should seem that three broad categories of pupils may be distinguished in the classroom. There are some pupils who enjoy science and all that goes with it in 
the classroom or laboratory. There is yet another group of those who don't like it. Even if the teacher prepares "exciting" experiments, this group of pupils is just not interested. There are also those who seem indifferent towards science. They occasionally participate if things are interesting but on the whole they appear neutral. A teacher, in his search for ways to help all students succeed, must recognize the importance of his students' feelings and what a strong effect they can have upon the amount of work done, the effort put forward and the learning that results [7]. Thus it is hardly surprising that a common feature of much good science teaching is likely to consist of attempts by the teacher to ameliorate the negative feelings or attitudes towards science, to arouse the indifferent ones, and to further strengthen the already positive ones.

For over a long period of time, there has been a growing trend to see Science Education as a means or tool for surviving the developmental and technological needs of the nation in general and society in particular, [8-10]. The educational philosophers, who hold this view, see the school as the agent of social reform. They believe that the social, political and economic world outside the school can be changed, if not completely or partly by introducing changes in the content of Science Education, [11]. It is further argued that while there must be provision within education for self-actualization, the values, cognitive skills and competencies developed should turn out human resource to develop society in a desired direction.

Generally, the democratization of Education opportunity created implications that few pupils would likely find places in institutions of higher training and learning. Consequently, Science Education, particularly at Secondary school level, is expected to prepare the majority of pupils for the world of work, [12].

As in many other developing nations [13-15], science and technology ( $\mathrm{S} \& \mathrm{~T}$ ) education is seen as a vehicle for economic and social advancement. Zimbabwe's Five Year National Development Plan [13] stated: "Development of Science and Technology is Zimbabwe's long term and most important strategy for economic and social development (p. 84)".

A study on Secondary school pupils' attitudes towards Science is perhaps, a plumb line or indicator on the nations' future technological focus. It would be desirable that such planning and expectations are based upon and presuppose that, while in school, pupils develop positive and favourable attitudes towards teaching and learning of Science. Perhaps, if attitudes are positive they will excel academically and so that they can willfully utilize this knowledge later in the productive sector as workers. Negative feelings or attitudes would be expected to discourage further exposure to scientific inquiry or to science-related careers and occupations [16-18].

The importance of attitudes to school learning has long been recognized [19-22]. Most research in assessing attitudes towards Science was carried out amongst school children. Two studies of relative popularity of school subjects [23-24] showed that physical sciences rank low in the preferences of Secondary school pupils. Studies of children's questions and interests [25-26], however suggested that interests in Science develop at an early age and that up to the age of fifteen the majority of questions which children ask spontaneously are of a scientific nature. Some study by [27] in the preferences of Grammar school pupils in U.K. concluded that:

a) At the Ordinary Level stage, science specialists showed a preference for science and arts specialists for arts subjects but a substantial minority favoured both and the tendency to favour both was stronger among the science specialists.

b) At the Advanced Level, over $40 \%$ of Science specialists would have preferred an arts subject, less than a third would have confined their choice to science if four ' $A$ ' levels were taken. The proportion of arts specialists preferring a science was smaller and there exists a strong "core" of arts specialists whose interests are limited to arts subjects.

One hundred and fifty children between the ages of twelve and fifteen were studied continuously for ten weeks on three aspects of Science interest, i.e. in scientifically biased leisure activities, scientific method and topics in the general science course. No difference in interests was found for boys and girls and there was no link with general intelligence, the science mark or the attitude of the child towards the science teacher. The study produced a series of recommendations which might have a cumulative effect on the development of interest in science amongst children.

Reference [28] used a series of data from intelligence tests, science tests, interest tests and teachers' assessment and identified three factors, viz general scientific ability, scientific interest and general intelligence as contributing to achievement in science. Studies of attitudes towards aspects of science have also been carried out by [26]. A jury was used to identify positive and negative attitudes among high school pupils and the study found that whereas the pupils showed constructive attitudes towards science, they showed substantially no constructive attitudes towards the scientist and his work and the nature of science; the higher the I.Q. (as measured by a short vocabulary test) the more favourable the attitude. [26] used the Purdue Physical Science test to measure aptitude and the Purdue opinion panel for attitudes and found that in general attitudes were favourable. There was a significant relation between attitude towards scientists and aptitude but not between science as a vocation and aptitude. However attitudes to science as a subject and to scientists were related to the pupils grades in science and to their socioeconomic status.

Reference [26] found no significant differences between science and non-science groups in their attitudes towards science and scientific careers. [29] examined the effects of a physical science course for non-science majors (PSNS) which aimed to provide "a better attitude of open mindedness" towards science and a greater understanding of science in contemporary society. A dogmatism scale of Milton Rokeach and facts about Science test showed no 
significant difference between groups following the PSNS course and other groups. However, [30] found a significant difference in the critical thinking ability between chemistry and non-chemistry students and a positive gain in attitudes towards science by chemistry students and not by nonchemistry students. As a control, no significant difference was noted between different groups of chemistry students or between different groups of non-chemist students in their critical thinking ability.

Reference [31 p.15] identified a Model of the nature of science composed of eight assertions about the characteristics of Science. An initial series of two hundred short statements about the nature of science were prepared and eventually reduced to twenty-nine (29) items on a Likert - type scale, which become the Nature of Science Scale (NOSS). The scale was administered to professional scientists, science teachers and psychology majors.

The surprising outcome and only significant difference was "the better understanding by psychology majors of the methodological aspects of science as the main reason for their scoring higher in the overall measurement of scientific understanding". There was no significant difference in the results between scientists and science teachers; neither experience nor time since graduation affected the concept of the nature of science for the population under study. Some concern was expressed about the low level of the scores by all groups (mean scores of about 35 out of a possible 59) and the significantly higher scores of psychology majors suggested that more attention might be paid to the philosophy of science in courses for science majors. The first study by [32], following the analysis of fifty (5) hours of tape recorded information collected from small groups of 12 to 13 years old pupils discussing freely science and science teaching and science and scientists, produced an adverse picture for a stereotype of a scientist. The second study by [33] consisted of an examination of scripts in answer to Question 2.2 in a G.C.E 'A' Level General Studies paper, viz:

"Try to account for the fact that the number of students wishing to study arts and social sciences at universities is increasing more rapidly than the number wishing to study natural sciences". The list of arguments presented by the sixth formers were grouped into seven (7) categories but the three most important, for girls and boys, were high level of intelligence required, little scope for self-expression, boredom in Science lessons. Girls tended to give the following reasons: - the late introduction of science, a desire to help the community directly and a shortage of staff, whereas boys placed fairly high: the poor image of a scientist, his personality and job.

Reference [32] surveyed the views of science teachers and found that there was some denial about a swing from science and suggestion "of a shift of emphasis from physical to biological science". Reasons for the swing came in two categories:

a) Science teachers were either too young and inexperienced or too old and out of date. Specialist teaching in the sixth form left no time for junior school teaching. There were conflicting views about the influence of syllabuses and examinations (the report commented that curriculum reform appears to coincide with the swing away from science).

b) Subject of Science is too complex and too demanding in time and energy. Science has an impersonal nature which is not attractive to sixth formers who are more socially conscious than previously.

A project "Attitude towards Science" was initiated by [13]. The aim of the project was to design and develop a questionnaire which:

a) defines the important boundary areas of Secondary school pupils' attitudes towards science.

b) develops reliable and valid scales which measure these boundaries and

c) relates scores on these scales to other relevant variables. Over 300 attitude statements were initially prepared from interviews with pupils. Two 97 - item questionnaire were administered to 500 all-age pupils and 600 fourth and fifth formers. Factor analysis of the results yielded five groups, viz: Science in my life, Science in society, learning activities in Science, science teachers and school.

All the 70 items in the five groups were arranged in Likert-scale form and the final questionnaire printed in two forms in order to ascertain the reliability of the instrument. The test was administered to fourth form pupils together with nine (9) other tests in order to establish relationships which may have existed between attitudes towards science and personality or scholastic ability. The final report on this wasn't available [34] found out that British children had deteriorating attitude towards Science. They say "......abundantly clear that the values implicit in our technological society have become widely discredited because technology is seen as potentially destructive to important aspects of living ....the crucial change in direction has been away from doing and towards feeling. The young seem less interested in Science, factual knowledge and cognitive mastery in general the very skills which underlie technical efficiency".

This seems to be the opposite in Zimbabwe. From classroom observations, it would seem that school pupils, who are bright, are the ones who are motivated to pursue some scientific work, even on their own. The not so bright ones shun, or look down upon science. They are not interested. They have negative attitude.

Reference [35] asserts that; "Instead they (the children) seem to express a mood of irrationality, they delight in fantasy..... the exaltation of inner freedom, of the exploration of subjective experiences, the fullest possible realization of one's personality."

Similar claims have been made in America where [35] says, "...apparently American youth is now characterized by virulent anti-bureaucratic and anti-technological 
animus ..... these descriptions of pervasive antagonistic attitudes towards science do not yet appear to have been substantiated by empirical evidence".

A positive relationship between attitude and achievement was demonstrated by several researchers [36-39]. [5] found evidence of a causal link from attitude toward achievement. [40] concluded however, that the relationship between attitude and behavior is probably correlational rather than literal, and that although attitude may be a valuable predictor of achievement, it is not necessary a causal factor. Nonetheless, changes in behavior can be expected to accompany modifications of attitudes [41].

Further research has suggested that there are important variables which should, or can be modified to bring about the desired changes in interest and achievement. Such important variables include the curriculum, teacher quality and characteristics, and a diversity of classroom factors [42-43, 39, 44]. Evidence is insufficient, however, to identify the most predictive of those variables. The situation is further complicated by the observation that these variables tent to interact, thus forming complex clusters of influence, [45].

Studies by $[46-47,44]$ gathered the perceptions of students of various ages towards science classes, teachers, and course content. These investigations concluded that student attitudes toward school science were generally impoverished, and that student interest in Science diminished with time spent in school. Comparisons of exemplary and random programs [48-49, 47] identified differences in instructional techniques, teacher characteristics and classroom environments. Students in exemplary programs tended to report more positive attitudes towards science teachers and classes than did students in random programs.

Two studies, [46, 50], compared the perceptions of 9 -, 13-, and 17- year old students with those of young adults (age 25-35). Although these studies corroborated the conclusion that student interest in science decreases with years of formal education [1], an even more distressing finding was that the young adults were more negative about the quality of their science experiences than were any of the school age subjects. [46] noted however, that the young adults, "tended to be non-college persons who remained in their local communities as a part of the labour force" ( $p$. 413).

It is therefore the proposition of this study that there are several variables that are useful in promoting positive attitudes towards Science. Some studies were conducted on the relationship between pupils' attitudes towards education and the influence of their homes [45, 51]. These studies showed a significant relationship between various factors of the home, particularly the fathers' education and the work he does on the one hand and the pupils' attitudes towards education on the other.

In a comparative study of performance in Physics and Chemistry of 14 year old pupils from Zambia and Zimbabwe, [51] made a number of findings regarding the influence of the home on attitudes towards and performance in the science subjects. He found that children who received greater encouragement from their parents had positive attitudes towards education and performed significantly better than those who did not receive encouragement. The parent's education, particularly the father's education was also found to be a factor that influenced the children's performance. Although attitudes and performance of children were not to a great extent dependent on the socioeconomic status of the home, it was found that the father's occupation had the most powerful (of all the home variables) influence on performance.

It is against this background that I found it imperative to study in Zimbabwe the effect of parental antecedent variables against total attitudes of pupils towards the learning and teaching of Science.

\subsection{Hypothesis}

On the basis of studies of attitudes toward Science [52$53,18]$ the following main Null hypothesis was examined, stated thus: There is no significant difference in students' total attitudes towards teaching and learning of science and parental antecedent variables. The variables studied are:

- Parental encouragement to learn science

- Parental level of education

- Parental gender

- Parental socio economic status

\section{Methodology}

\subsection{Research Method and Design}

A simple survey design based on a questionnaire with 65 items of the 5 point Likert scale type was designed. Permission to go into schools was granted by the Provincial Office of the Ministry of Education. The participants were asked to complete all the questions on the Likert type scale continuum based, whether they agreed, strongly agreed, disagreed, undecided, disagreed or strongly disagree.

The participants were asked by the author whether there were any items which were difficult to understand. Their responses were taken into consideration. Some items were then modified and reworded. Factor analysis was used, using principal components factor analysis with varimax rotation, Kaiser normalisation and scree testing, partly to determine validity and reliability coefficients of instrument and categorisation of factors. Variables with factor loading of 0.3 and above and eigen values of 1 and above were considered for the main research study [54]. Such factors accounted for $80 \%$ of the variance. A factor analysis for a three factor solution in line with the theoretical dimension of attitudes was sought. The instrument appeared to have content validity, since the author, through the help of a colleague, tried to verify the relationship between content and purpose of instrument [54].Great effort was taken at the construction stage of the questionnaire. Care was taken to use a level of language commensurate with the level of 
education of subjects. The split half-alpha reliability and Cronbach reliability was .68 and .61 respectively suggesting adequate reliability of the attitude toward Science (ATS) scale since the alpha and Cronbach values are relatively high enough [55-56].

\subsection{Participants}

Two hundred and forty-three participants randomly selected from Gweru urban district secondary school pupils took part in the main study. One hundred and fifteen were female students and one hundred and twenty-eight were male students. Forty-nine of the subjects were in form one, thirty-four were in form two, ninety three were in form three and sixty seven were in form four. Systematic randomization was used to produce 243 participants

During administering the questionnaire, the author guarded jealously against interpreting any part of the questionnaire to any student. This was done to increase validity and reliability of instrument. Data were analysed using the SPSS - PC program [57]. The hypothesis was tested using Analysis of Variance statistics (ANOVA) and one way Anova statistics. The independent variables were parental encouragement of children to learn science, parental level of education, parental sex, and parental socio-economic status. The dependent variable was pupil total attitude. The level of significance adopted, were the probability of rejecting a true null hypothesis and accepting a false alternative hypothesis or Type 1 error, and the sample size. In this study the hypothesis was tested using 3 levels of significance. These were 0,$05 ; 0,01$ and 0,001 . The 3 levels of significance cited above, are all relatively high levels of significance which increase the chances of committing type II errors in the decision making.

Analysis of variance (ANOVA) statistics were employed in order to examine the relationship between the independent and dependent variables. It was also used to test the hypothesis that several population means are equal.

\subsection{Ethical Considerations}

Participants in the study gave their consent in writing before commencement of the study after the purpose of the study and what would be expected of them had been explained. They were assured that they were free to withdraw at any stage without any negative consequences. Pseudonyms were assigned to participants to maintain and guarantee anonymity and confidentiality [3].

\section{Results}

\subsection{Antecedent Variables by Pupil Total Attitude About Science}

Table 1 shows the Analysis of variance statistics for total attitude of pupils towards teaching and learning of Science by parental demographic characteristics, (antecedent variables).

Table 1. Anova for pupil total attitude variable about Science by parental demographic variables $(N=243)$.

\begin{tabular}{|c|c|c|c|c|c|c|}
\hline Source of Varianc & Mean Square & Df & Means & F-Ratio & Sign. of $F$ & Eta \\
\hline Main effects & 8049.691 & 5 & 82.643 & 5.624 & $.000 * *$ & .39 \\
\hline $\mathrm{P} /$ encouragement to learn science & 1608.301 & 1 & 40.438 & 7.388 & $.005^{*}$ & .19 \\
\hline Parental level of education & 1944.388 & 1 & 46.293 & 8.991 & $.004 *$ & .21 \\
\hline Parental sex & 1933.444 & 1 & 46.091 & 9.124 & $.001 *$ & .21 \\
\hline Parental socio economic status & 2193.755 & 1 & 47.532 & 10.556 & $.000 * *$ & .19 \\
\hline
\end{tabular}

**Significant at $\mathrm{p}<.001$ level; *Significant at $\mathrm{p}<.01$ level

The main effects for each of parental encouragement of their son / daughter to learn Science at school $(\mathrm{F}=7.388$; $\mathrm{p}=.005<.01)$, parental level of education $(\mathrm{F}=8.991 ; \mathrm{p}=$ $004<.01)$, parental sex $(\mathrm{F}=9.124 ; \mathrm{p}=.001<.01)$, parental socio-economic status $(\mathrm{F}=10.556 ; \mathrm{p}=.000<.001)$, were significant. Thus, for total attitude variable, the sources of variance were parental encouragement to learn Science, parental level of education, parental sex and parental socioeconomic status.

Similarly, interaction effects for all the variance were significant, $(\mathrm{F}=5.624 ; \mathrm{p}=.000<.001)$. The demographic variables of parental encouragement to learn Science, parental level of education, parental sex and parental socioeconomic status reflected significant variance at .01 level, ETA values for above variables are as follows: parental encouragement to learn Science, (.19) parental level of education, (.21) parental sex, (.21) and parental socioeconomic status (.19). These values for the above demographic variables accounted for the observed alphas at .05 or less.
It is interesting to also note that all the demographic variables above are important in explaining the total pupil attitude towards the teaching and learning of science. Therefore the hypothesis that there is no significant difference in students' attitudes towards teaching and learning of science and parental antecedent variables is rejected.

\subsection{One-Way Analysis for Total Attitude of Pupils by Parental Demographic Variables}

Table 2 shows a one way analysis computer for total attitude by independent (demographic) variables. It was observed that although parental encouragement of children to learn science, parental level of education, parental socio economic status, and parental sex were significant in Table 1 of ANOVA, the one way analysis only showed parental encouragement of children to learn science, parental level of education, and parental socio economic status being significant with parental sex (gender) failing to explain a 
significant proportion of the variance in total attitude $(\mathrm{F}=1.1260 ; \mathrm{p}=.1341>.05)$. This implies that there are differences in total attitude towards the teaching and learning of Science amongst male and female parents.

Table 2. One way analysis for pupil total attitude by parental demographic variables

\begin{tabular}{|c|c|c|c|c|c|}
\hline Variable & Source & Df & Means & F-rato & F-Prob. \\
\hline $\begin{array}{l}\mathrm{P} / \text { encouragement } \\
\text { to learn science }\end{array}$ & $\begin{array}{l}\text { Between } \\
\text { groups }\end{array}$ & 3 & 36.85 & 6.5432 & $.0001 * *$ \\
\hline $\begin{array}{l}\text { Parental level of } \\
\text { education }\end{array}$ & $\begin{array}{l}\text { Between } \\
\text { groups }\end{array}$ & 3 & 12.47 & 0.6984 & $.0611 *$ \\
\hline $\begin{array}{c}\text { Parental socio } \\
\text { economic status } \\
\text { (s .e. s.) }\end{array}$ & $\begin{array}{l}\text { Between } \\
\text { groups }\end{array}$ & 1 & 24.90 & 0.6984 & $.0021 *$ \\
\hline Parental sex & $\begin{array}{l}\text { Between } \\
\text { groups }\end{array}$ & 1 & 15.07 & 1.1260 & .1341 \\
\hline
\end{tabular}

*Significant at the $\mathrm{p}<.01$ level**Significant at the $\mathrm{p}<.001$ level

\section{Discussion and Conclusions}

The study set out to investigate parental antecedent variables to students' total attitudes toward science teaching and learning. Attitude towards science have been observed to influence general academic performance in the science discipline [36-37].

The results of this study suggest that there are a number of factors that influence secondary school pupils' attitude towards the learning and teaching of science. This was especially so with regards to parental socio economic status, parental level of education, parental encouragement towards learning and teaching of Science.

There was some significant relationship between parental level of education and pupil's attitude towards the teaching and learning of Science. The results of this study corroborated some previous studies cited above. By virtue of the parent(s), (father in particular) being educated, this education is a pre-requisite for their children to have a positive attitude towards Science. [51] reported that the education and job of the father and his career ambitions for the child may be strongly related to a pupils' attitude towards a school subject.

It is interesting to observe that, the education of parents has a positive impact on their children's attitude towards science. Involvement of parents in their children learning of science is crucial to the attitudes developed by their children towards science learning. I will argue that the more intensely parents are involved in the education of their children, the more confident and engaged their children become as learners. Parents of higher socio economic status, higher level of education encourage their sons and daughters to learn sciences. They value sciences by virtue of their academic enlightenment. They also recognize tremendous opportunities that can arise from being more scientifically and technologically literate and better prepared to participate in the $21^{\text {st }}$ century science and technological workforce. Parents (whether it is the father or mother) have a critical role to play in encouraging and support their children's' science learning at home, in school and through their communities. Teachers also play an important role in this effort and can be valuable partners with parents in cultivating science learning confidence and attitudes towards the learning and teaching of science.

The results of this study indicate that attitudes towards science and learning remain an important issue in Education [1]. Three variables out of four have significance as far as pupil attitudes towards science teaching and learning are concerned. This is not to say though, that the variable which appeared insignificant is not to be taken into cognizance (parental sex).

The study was confined to participants in urban set-up hence there are variances that could introduce distinct differences in attitudes, between them and those in rural settings. There is need to carry out further investigations which encompass urban and rural settings of all provinces in Zimbabwe, if the results are to have external validity.

Students' attitudes were measured without considering the differences which could have resulted because of the different environments of different types of schools. Therefore further research needs to be carried out which will further split the schools into various other categories to enhance precision.

In pursuing this study, it was not in the hope of finding out the practical solutions to problems, but rather in the hope that findings would be relevant to understanding of attitudes towards teaching and learning of Science [1]. It was not possible, in this study, to link pupil's attitude with their Science performance in class and career aspirations. Future study in this area is therefore called for, not only to seek answers to these questions but also to further investigate the relationships between pupils' attitudes towards science subjects and pupils' perceptions of the world of science at work.

Like in any research in social sciences, the methodology used has its own limitations. Therefore, the results established in here need replication. This study has therefore laid down the foundation and groundwork to further studies on learning research within the context of Zimbabwean Educational System.

\section{References}

[1] Gudyanga, E., \& Gudyanga, A. (2013). Attitudes of secondary school pupils towards the teaching and learning of Science. The Zimbabwean Case. International Journal Advances in Social Sciences and Humanities, 1(2), 1-6.

[2] Hodzi, R. A. (1992). Relationship of attitudes toward self, family, and school with attitude towards Science among Secondary school students in Zimbabwe. Zimbabwe Journal of Educational Research, 4(3), 294-305.

[3] Gudyanga, A., Kathija, A., \& Kurup, R. (2013). Zimbabwean female participation in physics: The influence of context on identity formation. Department of Education. Nelson Mandela Metropolitan University. South Africa. 
[4] Urgulou, M. E., \& Walberg, H. J. (1981). Motivation and Achievement in Science. American Educational Research Journal, 24(1), 87-91.

[5] Schibeci, R. A., \& Riley, J. P. (1986). Influence of students' background and perceptions on Science attitudes and achievement. Journal of Research in Science Teaching, 23, 177-187.

[6] Mager, R. (1991). Attitudes towards Science. A quantitative synthesis. Science Education, 34(3), 337-353.

[7] Fishbein, M., \& Ajzen, I. (1975). Belief, Attitude, Intention and Behaviour: An Introduction to theory and Research. Reading - Mass: Addison - Wesl

[8] Lillis, K. (1982). The Growing Importance of the Vocational School? Paper in press. SIDA A.G.M. (SIDA).

[9] Moyo, N. S. (1988). Problems in the teaching of Practical subjects. Teachers Forum, 16(7), 23-24.

[10] Mackenzie, C. G. (1988). Zimbabwe's Educational miracle and the problems it has created. International Review of Education, 34(3), 337-353.

[11] Levin, H. M. (1978). Educational Reform: Its Meaning? The Limits of Education Reform. New York: Longman, Inc.

[12] MoESC. (2008). Director's Circular No. 23 Implementation Guidelines for the Institutionalisation of the Guidance and Counselling Programme in all Primary and Secondary Schools. Harare: Ministry of Education Sport and Culture.

[13] UNESCO. (1983). Science and Technology Education and National Development. Paris: UNESCO.

[14] Nichter, R. (1984). A Study of UNESO Science Education improvement projects in selected Anglophone countries of Africa: project problems. Science Education, 68(4), 381-396.

[15] Chisman, D. G. (1984). Science Educational and National Development. Science Educational and National Development, 68(5), 563-569.

[16] Fazio, R., \& Williams, C. (1986). Attitude accessibility as a moderator of the attitude-perception and attitudebehaviour relations: An Investigation of the 1984 presidential election. Journal of Personality and Social Psychology, 7, 505-514.

[17] Schibeci, R. A. (1989). Home, School and Peer Group Influences on student attitudes and achievement in Science. Science Education, 73(1), 13-24.

[18] Gogolin, L., \& Swartz, F. (1992). A quantitative and qualitative inquiry into the attitudes toward science of nonscience college students. Journal of Research in Science Teaching, 29, 487-504.

[19] Edwards, A. L., \& Kenny, K. C. (1946). A comparison of the Thurstone and Likert techniques of attitude scale construction. Journal of Applied Psychology, 30, 72-83.

[20] Likert, R. (1932). A technique for the measurement of attitude. Journal of Social Psychology, 1(4), 55-57.

[21] Likert, R. (1934). A simple and reliable method of scoring the Thurstone attitude scales. Journal of Social Psychology, $5,228-238$.

[22] Simpson, R. D., \& Troost, K. M. (1982). Influence on commitment to and learning of Science among adolescent students. 66, 5, 761-781. Science Education, 66(5), 761-781.

[23] Pritchard, R. A. (1935). The Relative popularity of Secondary School subjects at various ages. British Journal of Educational Psychology, 5, 229-241.

[24] Houslop, N. L., \& Weeks, E. J. (1948). The interests of school children. School Review, 4(3), 48-53.

[25] Ball, F. H. (1978). Teaching and Learning Mathematics and Science. Dubuque: Iowa, WC Brown.

[26] Allen, H., \& Stokes, R. Z. (1959). Professional Training of Teacher's. A Review of Research, 3, 200-215.

[27] Lewis, D. G. (1963). An Investigation of the subject preferences of grammer school pupils. Durham Research Review, 3(3), 132-135.

[28] Angus, L. (1950). A comparative study of the methods of measuring interest in Science and its relation to ability and achievement. British Journal of Educational Psychology, 20, 63-65.

[29] Johnstone, A. H. (1982). Attitude measurement in Sciencepitfalls and pointers in Royal Society of Chemistry"Chemical Education Research and its implications for teaching.". Paper presented at the Proceedings of a symposium, University of Aston, University of Aston, Birmingham.

[30] Brown, T. R. (1967). Attitude towards Science and Critical thinking abilities of Chemistry and Non-Chemistry students in the Tacoma Public-schools. School Science Review, 31, 231-234.

[31] Kimball, M. E. (1967). Understanding the Nature of Science - a comparison of Scientists and Science teachers. 5, 2, 67-68. Journal of Research in Science Teaching, 5(2), 67-68.

[32] Whiston, T. G. (1969). Future Trends in Science Education. Education in Chemistry, 6(4), 3-8.

[33] Wesley, S. J., \& Meredith, A. S. (1983). Predicting student performance in a University Department of Education. British Journal of Educational Psychology, 49(16), 238-242.

[34] Allen, H. (1959). Attitudes of certain high school seniors towards Science and scientific careers. Research in the Teaching of Science, 2, 279-281.

[35] Gardner, P. L. (1975). Attitudes to science: A review. Studies in Science Education, 25, 283-289.

[36] Cannon, R. K., \& Simpson, R. D. (1985). Relationships among attitude, motivation, and achievement of ability grouped, seventh-grade, life Science students. Science Education, 69, 121-138.

[37] Germann, P. J. (1998). Development of the attitude toward science in school assessment and its use to investigate the relationship between science achievement and attitude toward science in school5(8) 689-703. Journal of Research in Science Teaching, 25(8), 689-703.

[38] Hough, L. W., \& Piper, M. K. (1982). The relationship between attitudes toward Science and Science achievement. Journal of Research in Science Teaching, 19, 33-38.

[39] Talton, E. L., \& Simpson, R. D. (1987). Relationship of attitude toward classroom environment with achievement in Science among tenth grade Biology students. Journal of Research in Science Teaching, 24, 507-525. 
[40] Shrigley, R. L., Koballa, T. R., \& Simpson, R. D. (1988). Defining attitude for Science Educators. Journal of Research in Science Teaching, 25, 659-678.

[41] Shrigley, R. L. (1983). The attitudes concept and Science teaching. Science Education, 67(4), 425-442.

[42] Haladyna, T., \& Shaughnessy, J. (1982). Attitudes towards Science: A quantitative Synthesis. Science Education, 66, 554-563.

[43] Koballa, T. R., \& Crawley, F. E. (1985). The influence of attitude on Science teaching and learning. School Science and Mathematics, 85, 222-232.

[44] Yager, R. E., \& Yager, S. O. (1985 ). Changes in perceptions of science for third, seventh, and eleventh grade students. Journal of Research in Science Teaching, 22(4), 347-358.

[45] Keeves, J. P. (1975). The home, the school, and achievement in Mathematics and Science. Science Education, 59(4), 439-460.

[46] Yager, R. E., \& Bonnstetter, R. J. (1984). Student perceptions of Science teachers, classess and course content. School Science and Mathematics, 84, 406-414.

[47] Yager, R. E., \& Penick, J. E. (1984). What students say about science teaching and science teachers. Science Education, 68, 143-152.

[48] Bonnstetter, R. J., Penick, J. E., \& Yager, R. E. (1983). Teachers in Exemplary programs: How do they compare. Washington, DC:: National Science Teachers Association.
[49] Yager, R. E. (1988). Comparison of Perception: Exemplary Science and Random Programs. School Science and Mathematics, 88, 37-46.

[50] Yager, R. E., \& Penick, J. E. (1986). Perceptions of four age groups toward science classes, teachers, and the value of science. Science Education, 70, 355-363.

[51] Clifton, R. A. (1978). Socioeconomic Status, Attitudes and Educational Performance. Tockholm: Almqvist and Wiksell International.

[52] Myers, R. E., \& Fouts, J. T. (1992). A cluster analysis of high school Science classroom environments and attitude toward Science Journal of Research in Science Teaching, 29(9), 929-937.

[53] Yore, L. D. (1991). Secondary Science Teachers' Attitudes toward ad beliefs about Science Reading and Science Textbooks. Journal of Research in Science Teaching, 28(1), $55-72$

[54] Rust, J., \& Golombok, S. (1989). Modern Psychometrics. The Science of Psychological assessment.

[55] Helmstadter, G. C. (1988). Scientific principles of psychological measurement. New York: Appleton -Century-Crofts.

[56] Mason, E. J., \& Bramble, W. J. (1991). Understanding and conducting Educational Research: Applications in Behavioural Sciences. New York: Mcgraw-Hill Book Co.

[57] Hull, C. H., \& Nie, N. H. (1984). SPSS. New York: Macgraw-Hill.London: Amazon. 